\title{
A OUSADIA DA MUDANÇA
}

THE DARING OF CHANGE

LA OSADÍA DEL CAMBIO

Oscar Cirino*

Resenha:

Machado, R. (2017). Impressóes de Michel Foucault. São Paulo: N-1.

\section{A OUSADIA DA MUDANÇA}

oberto Machado é um dos principais responsáveis pela difusão, no Brasil, do pensamento de um dos mais importantes filósofos contemporâneos: Michel -Foucault. Traduziu alguns de seus livros, deu cursos, conferências, orientou teses, escreveu sobre sua obra e, utilizando-se de sugestóes do próprio Foucault, empreendeu, com alguns amigos, importante pesquisa sobre a constituição histórica da medicina social e da psiquiatria no Brasil. Roberto Machado também frequentou cursos e seminários do filósofo no Collège de France, em Paris, no período de 1973 a 1981. Desse contato intelectual brotou, com seus mistérios, uma amizade tecida pelos estudos conjuntos na Bibliothèque Nationale, pelo prazer da boa conversa nos jantares e reunióes no apartamento de Foucault e pelas viagens por diferentes praias e cidades do Brasil.

Seu novo livro sobre o pensador francês, Impressões de Michel Foucault, é motivado pela saudade, definida pelo autor como a "vontade de eternizar a beleza das coisas que passam". Ele se inicia e termina com o impacto e perplexidade causados pela morte inesperada, em 1984, de Michel Foucault, aos 58 anos, ecoando o que escreveu o sociólogo alemão, Norbert Elias: "A morte não encerra nenhum mistério. É o fim de um ser humano. O que sobrevive é o que ele deu aos outros seres humanos, o que permanece em sua lembrança”.

$\mathrm{Na}$ tentativa de deter a fugacidade do tempo, Roberto Machado recorre à sua memória, relembrando sua atividade política em organizaçôes ligadas à Igreja, sua formação acadêmica, seu percurso intelectual e sua vida afetiva. A seleção dos episódios que constroem a narrativa contempla, concomitantemente, a memória individual do autor e a coletiva, tanto da situação política e universitária brasileira

*Mestre e bacharel em Filosofia pela Universidade Federal de Minas Gerais, psicanalista. Endereço: Rua dos Aimorés, 2631, ap. 1001 - Santo Agostinho, Belo Horizonte-MG, Brasil. CEP: 30140-076. E-mail: ocirino@uol.com.br. 
quanto do contexto intelectual europeu a partir da década de 1960.

Sem temer a mudança, o autor ousou uma escrita bem diferente de seus reconhecidos artigos acadêmicos e livros anteriores sobre o pensador francês: Ciência e saber: a trajetória da arqueologia de Foucault (1981) e Foucault, a filosofia e a literatura (2000). Nesses textos, a articulação rigorosa dos conceitos e argumentos, como requer a tradição filosófica, é empreendida com afinco e clareza.

Agora, Roberto Machado nos apresenta essas “impressōes” que, como indica o Houaiss, constituem-se num "gênero literário próximo da crônica, em que se mesclam sensações, sentimentos, reflexões e relatos". A leveza de seu estilo envolve o leitor em passagens saborosas, como quando convida Michel (é assim que Foucault, muitas vezes, é intima e afetuosamente nomeado) para provar o suco do "fruto de sua infância", e este lhe diz sem piedade que não gostou. Apesar de radicado há anos no Rio de Janeiro, os vestígios de sua infância e juventude no Nordeste ressoam em sua voz e nessa descrição poética que faz da mangaba: "Uma frutinha delicada, de sabor doce-amargo, casca macia finíssima, menos que casca, simples película”. A leitura é também às vezes assaltada pelo humor, como quando se refere ao modo com que Gilles Deleuze se apropriou do pensamento de Foucault e de outros na construção de sua filosofia: "Como a Pantera Cor-de-Rosa, Deleuze mais uma vez queria pintar o mundo com suas cores". O último capítulo, A terra do sol, narra, quase como um roteiro turísticoafetivo, o tour que realizou com Foucault pela orla de Salvador, por Olinda e pelo agreste pernambucano.

\section{O APREÇO CONCEITUAL}

No entanto, o livro não se restringe ao testemunho das marcas produzidas pelos gestos e sorrisos, pela coragem e comentários de Michel. Sua vertente filosófica manifesta-se nas sínteses primorosas das mais importantes ideias dos principais livros de Foucault, como também dos livros do próprio Roberto Machado. Ele deixa clara a importância de não se criar uma "ilusão retrospectiva" na leitura da obra do pensador francês, ainda que o próprio Foucault faça isso algumas vezes em entrevistas. Em outras palavras, trata-se de não projetar o Foucault mais recente para entender o Foucault do passado. O pensamento dele não é sistemático, e ele não se apega ao que já havia pensado, preservando a liberdade de se desprender e propor novos caminhos. Talvez um dos poucos traços constantes em sua proposta de estudar os problemas filosóficos da verdade e do conhecimento por meio de análises históricas seja a importância dada à dimensão instrumental do pensamento, visando a sacudir evidências e impulsionar lutas políticas concretas. 
Para quem deseja pesquisar utilizando-se das ideias de Foucault, o autor sugere que os cursos no Collège de France (quase todos já traduzidos no Brasil) são bem mais interessantes de que seus livros. Nos cursos, é possível acompanhar o modo como Foucault pesquisava e trabalhava na elaboração de seu pensamento, enquanto os livros já seriam a conclusão do processo. Machado qualifica também algumas obras de Foucault. Assim, As palavras e as coisas é o livro "mais difícil e ambicioso", os dois últimos volumes da História da sexualidade são "os mais sóbrios e serenos" e A arqueologia do saber é "metódico demais, abstrato demais".

\section{NA BUSCA DE UM ESTILO}

Em seus estudos em Paris, na maioria das vezes realizados nas férias universitárias no Brasil, Roberto Machado seguiu as aulas de Jacques Derrida, Roland Barthes, Michel Serres, entre outros, além de Foucault e Deleuze. Como também já era professor, ao mudar de papel, o autor acompanhava não somente o conteúdo, mas também o estilo das aulas e, nesse percurso, concluiu que "um professor é, antes de tudo, um aluno capaz de escolher o tema de seus estudos e se dedicar a ele enquanto lhe interessa”.

De todos esses mestres, entusiasmou-se, além de Foucault, especialmente com Gilles Deleuze, quem orientou seu pós-doutorado e cuja obra motivou traduçôes e também a escrita de dois livros. Seguiu durante anos seus cursos, juntamente com os de Foucault, e se encantou com a maneira prazerosa e elegante que ele transmitia seu enigmático pensamento. Além disso, ambos bebiam das fontes fecundas de Nietzsche. Desse modo, podemos compreender por que a relação e o contraponto entre Foucault (um pensador sem aliados) e Deleuze (um filósofo da aliança) são contemplados em dois capítulos: Uma época, dois estilos e Amigos separáveis. Neles, além de comparar o estilo dos dois filósofos, no modo como ministravam suas aulas, proferiam suas conferências ou como coordenavam seus seminários, levanta hipóteses sobre os motivos da separação entre os outrora bons amigos e parceiros.

O panorama intelectual europeu da época é abordado em torno de debates e polêmicas, seja pela busca da filosofia francesa de se afirmar diante da tradição filosófica alemã, seja em torno da relação de Foucault com a fenomenologia, o existencialismo, o estruturalismo, o marxismo, Althusser, Habermas, a Escola de Frankfurt, sendo que as questões suscitadas pelo pensamento de Marx e pela psicanálise, em especial Lacan, recebem tratamento privilegiado. Apesar de destacar o humor, a descontração e elegância de Foucault, Roberto não deixa de apresentar o aspecto rancoroso, às vezes cruel, do filósofo com alguns assistentes de seus cursos ou seminários, e especialmente com aqueles que o criticaram 
política e intelectualmente, como Sartre, Simone de Beauvoir, Derrida, Martial Gueroult, Lévi-Strauss, Jean Baudrillard, ou o cineasta Jean-Luc Godard.

Roberto Machado foi impactado, em uma de suas passagens por Paris, pela pergunta de um dos participantes dos seminários de Foucault: "Então, você é o apóstolo no Brasil?". Essa pergunta surpreendente, que obteve como resposta "Sou um simples discípulo. Apóstolos são os que vivem em torno do mestre", seguramente produziu efeitos fecundos para se afastar da confortável, mas preguiçosa "sombra de um gigante", título de um dos capítulos do livro. Em momento de maturidade intelectual, o autor, sem desconsiderar tudo que Foucault lhe transmitiu, prosseguiu seus estudos e pesquisas temáticas em Nietzsche, Deleuze, sobre o nascimento do trágico no pensamento alemão, Proust e as artes.

Ao cativar o leitor com a fluidez de uma escrita que entrelaça a precisa exposição das ideias de um dos mais importantes pensadores contemporâneos com relatos aprazíveis dos impactos causados pela intensidade de sua presença, essas Impressóes de Michel Foucault passam a ocupar lugar singular no panorama filosófico brasileiro. 